Культура и искусство 2(14) • 2013

\title{
Н. Н. Зубков \\ «Credo» и «cogito» \\ как историко-культурная проблема
}

\begin{abstract}
Аннотация: на конференции «Философская мысль и религиозный опыт», посвященной памяти философа, богослова и историка Н. М. Зёрнова, обсуждались проблемы отношения веры и знания в культурах разных стран и эпох. Анализировались философские смыслы библейской заповеди, роль религиозного опыта в деятельности лидеров Бенгальского Возрождения, типы религиозного сознания в современном российском обществе, вера и знание как основные категории истории европейской мысли и др. Отношения веры и знания раскрывались как одна из важнейших драматических, но вместе с тем и творческих коллизий в истории мировой и, в частности, отечественной культуры.

Ключевъе слова: культурология, культура, вера - знание - философия, наука и миф, религиозный опыт, традиционное мышление, гнозис, полидискурсность, В. Соловъев, Н. М. Зёрнов.
\end{abstract}

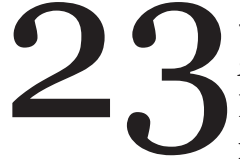
-24 ноября 2012 г. в Москве состоялась Первая конференция памяти Н. М. Зёрнова. Ее организаторами выступили: Научно-исследовательский центр религиозной литературы (и существующий на его базе Институт Библии) Всероссийской государственной библиотеки иностранной литературы (ВГБИЛ), Научно-учебный центр мировых религий Российского государственного гуманитарного университета (РГГУ), Центр проблем развития и модернизации Института мировой экономики и международных отношений РАН и журнал «Вопросы философии». Заседания проходили в помещениях ВГБИЛ и РГгУ. Конференция (их предполагается проводить ежегодно) была озаглавлена: «Философская мысль и религиозный опыт». В ходе конференции несколько уточнился основной обсуждавшийся аспект этой темы, который можно обозначить так: вера и знание в мировой истории и культуре (в хронологическом диапазоне от книг Ветхого Завета до современности).

Николай Михайлович Зёрнов (1898-1980) философ, богослов, историк, среди трудов которого особенно значительны монографии «Вселенская Церковь и русское православие» (1952) и «Русское религиозное возрождение XX века» (1963). Именно Зёрнов сделал историографически обоснованным последнее понятие, ныне прочно вошедшее уже не только в научный, но и в повседневный обиход. Как православный богослов, Н. М. Зёрнов искал догматического обоснования духа любви в отношениях между церквами, настаивая на том, что «ересь есть тяжкая болезнь, но не смерть церковного организма, и в том, что современное православное богословие перестало рассматривать ее как состояние болезни, и заключается причина всех наших нынешних колебаний по отношению к инославию». ${ }^{1}$ Наконец, но не в последнюю очередь, он собрал богатейшую коллекцию изданий Русского зарубежья, которую перед смертью завещал передать в Россию после падения коммунистической власти. Тогда почти невозможно было предположить, что всего 12 лет спустя это станет возможно и Библиотека иностранной литературы примет это собрание в состав своего фонда, что станет стимулом для новых направлений ее деятельности.

Этим заслугам Н. М. Зёрнова было посвящено вступительное слово модератора чтений Е. Б. Рашковского ${ }^{2}$. О них говорилось также 2в докладе А. Л. Рычкова, изложение которого мы представим ниже. Довольно камерная конференция (9 докладов, 33 участника за два дня заседаний) привлекла, тем не менее, ученых не только Москвы, но также Санкт-Петербурга и Пензы.

Первым на конференции был доклад Е. Б. Рашковского «Библия как источник философского вдохновения». Библия - не сама философия, у нее другой предмет, но она содержит в себе глубочайшие мировоззренческие интуиции, определившие собой опыт последующей мировой философии. Непосредственно предметом доклада был не обзор всех этих интуиций (который мог бы быть бесконечен), а одна сравнительно узкая, но проблемно насыщенная экзегеза: философская нагрузка проблемы Дня Субботнего в писаниях Ветхого и Нового Завета. Таким образом, доклад стал опытом философского вчитывания в религиозный текст, как бы практическим введением в проблематику веры и знания.

${ }^{1}$ Зёрнов Н. М. Англиканские рукоположения и Православная Церковь // Путь. № 59. 1939, февраль-апрель.

${ }^{2}$ К сожалению, не смог принять участия в конференции $\mathrm{H}$. В. Шабуров, также предполагавшийся модератором. 


\section{Философия культуры}

Само слово «Суббота» происходит от от корня -šb- («сесть» и, расширительно, «остановиться в трудах»). Современный переводчик Библии М. Г. Селезнев иногда переводит древнееврейское «шаббат» как «покой». Так, синодальному переводу «и почил Бог от дел Своих» (Быт. 2: 2) у него соответствует «пребывал в покое». ${ }^{3}$ Самый базовый фрагмент, на котором утверждается вся библейская философия Субботы, - завершение рассказа о сотворении мира (Быт. 2: 1-3): «1. Так созданы были небо и земля и весь порядок их. 2. И совершил Бог к седьмому дню все дела Свои, над которыми трудился, и успокоился от дел Своих, которые создал. 3. И благословил Бог седьмой день и освятил его, ибо в этот день успокоился <Бог> от дел своих, которые создавал и созидал» 4 . Здесь поразительное метафизическое и космологическое проникновение: Бог - безусловный Творец и Суверен твари, но у твари, от светил до человека, есть дарованный ей момент автономии: она живет, дышит и движется и после того, как Бог успокоился. А в самом Боге, создавшем человека по образу Своему и подобию, существует потребность мысли и созерцания, так что мысль и созерцание непреложно входят в состав бытия.

Антиномия закона и свободы развивается в Четвертой заповеди Моисеевой, которая дана в двух редакциях: в книге Исход (20. 8-11) и, более пространно, в книге Второзаконие (5.12-15). Толкуя их, необходимо помнить совет блаженного Августина: искать в книгах Ветхого Завета не преходящую экзотику древних времен, но непреложные духовные смыслы $^{5}$. Исследуя, казалось бы, архаический культурный норматив запрета на субботнюю работу, обнаруживаем в нем ряд философских измерений, в общем виде сводящихся к проблеме свободы.

1. Измерение метафизическое: у самих истоков бытия мысль, проект, воля, свобода и связанная с ней потребность в созерцании, репрезентации (поэтому необходим день, целиком посвященный Носителю этой мысли).

2. Измерение антропологическое: личное начало ценней автоматики мира. Тварный (падший) человек не может не работать, но ему дарована и свобода.

3. Измерение социальное: милосердие, жалость, социальная свобода ${ }^{6}$, преодоление ксенофобии

\footnotetext{
${ }^{3}$ Библия. Книги Священного Писания Ветхого и Нового Завета канонические. М.: РБО, 2011. С. 12.

${ }^{4}$ Докладчик использовал собственный перевод.

${ }^{5}$ Confess., 3, 6, V, 8.

${ }^{6}$ Особенно во Втор. 12: 14: «чтобы отдохнули, как и ты, и раб, и рабыня твоя».

7 Правило субботствования распространяется и на «иноплеменника в дому твоем» (Исх. 20: 10; Втор. 12: 14). Там же содержится и норма, относящаяся к экологическому, по Е. Б. Рашковскому, измерению.
}

задаются как непременные параметры человеческой истории.

4. Экологическое: сострадание эксплуатируемой нами дочеловеческой твари. Не случайно вол и осел из текста Второзакония стали атрибутом иконографии Рождества Христова.

В Новом Завете идея Субботы, субботнего покоя становится уже не столько прямым социально-регулятивным принципом, сколько категорией внутренней действительности человека, внутреннего устроения человеческой личности. Чрезвычайно обогащается антропологическое измерение проблемы субботствования: здесь работает установка не только на нормативные принципы Синайского законодательства, но и на развитие той высокой и тонкой культуры человеческого существования, на которую, по словам апостола Павла, уже «нет закона» ${ }^{8}$, которая, по существу, - превыше Закона. К сожалению, констатировал докладчик, историческое христианство не осталось на высоте этой новозаветной духовной интуиции.

Существует некоторое различие между трактовкой темы Субботы в Синоптиках и у евангелиста Иоанна, но в обоих вариантах идет речь о некотором жизнетворном парадоксе. Синоптики многократно повествуют о том, как Спаситель формально нарушал заповедь, творя в субботу исцеления, но сама возможность такого нарушения лишь подчеркивает святость как Целящего, так и самой заповеди: «Сын человеческий господин и субботы» ${ }^{9}$ У Иоанна субботний покой Господа (в гробу) и Его учеников (недоумевающих в горнице) - непосредственное предварение и условие «усилья Воскресенья», которым «Смерть можно будет побороть» (Б. Пастернак).

А. И. Черняк в связи с докладом высказал наблюдение, что последний парадокс дает также ключ к «живому» представлению о покое в физике, чтобы покой не понимался «обывательски» как отсутствие всякого движения и не упразднялся, как это фактически произошло в теории относительности, а стал сложным процессом взаимодействия невидимых сил ${ }^{10}$.

\footnotetext{
${ }^{8}$ Гал. 5: 23.

${ }^{9}$ Мф. 12:8; Мк. 2:28; Лук. 6:5. У Матфея эти слова даны как прямое следствие святости Иисуса: «Здесь Тот, Кто больше Храма».

${ }^{10} \mathrm{~B}$ том же духе можно еще заметить, что в христианской мысли покой Великой Субботы - не что иное, как оборотная сторона величайшего и напряженнейшего момента в истории мироздания: Сошествия во ад, т. е. собственно победы над смертью - условия освобождения всей твари («Во гробе плотски, во аде же с душею яко Бог, в раи же с разбойником, на престоле с Отцем и Духом...»). Аналогично и в быту именно в это время, с вечера Великой Пятницы, начинаются основные хлопоты по подготовке пасхального пира, происходит освящение куличей и т. д. (ср. у того же Пастернака: «У людей пред праздником уборка...») - и все это при сохранении строго субботнего характера богослужения (по крайней мере, православного) до самого момента, когда впервые провозглашается Воскресение.
} 
Культура и искусство 2(14) • 2013

Б. Е. Рашковский выступил с докладом «Йехудаха-Леви: вера, разум и традиция в “Книге доводов и доказательств...” .

Главное сочинение выдающегося еврейского мыслителя XII в. «Книга доводов и доказательств в защиту угнетаемой религии», более известное как «Сефер ха-Кузари» («Хазарская книга») или просто «Кузари», имеет форму беседы раввина с хазарским царем (мыслителемскептиком). В первой книге «Кузари» кроме них действуют еще аверроист, христианин и имам. Возможно, источником философского вдохновения для Йехуды ха-Леви явилась известная в его время переписка хазарских каганов с раввинами Испании. Если так, то это, возможно, единственный пример влияния текста исторической хроники на философское творчество.

«Кузари» - книга весьма многоплановая: она содержит и неоплатоническую критику перипатетизма, и критику христианства, ислама и караимизма, и апологию еврейского народа и его веры, и собственно хазарскую тему. Версий того, какая из этих тем является главной, существует множество. Докладчик сразу отвел в этом качестве критику христианства и ислама (их критикует не раввин - носитель мысли автора, а царь, да и то между прочим) и выдвинул свой тезис: ключевой для Йехуды-ха-Леви была проблема выбора, угодного и неугодного Богу. С этим связано само возникновение хазарской темы, так как в письме хазарского кагана Иосифа в Кордову (середина X в.) есть слова, сказанные Богом первому кагану, избравшему иудейство: «Я увидел твои поступки и одобрил твои дела». Йехуда этот ответ опять обращает в вопрос. В его трактате оживает сквозная тема религиозных культур раннего Средневековья: словопрения при выборе веры. Русскому читателю она знакома по «Повести временных лет», но встречается и во множестве европейских текстов ${ }^{11}$.

В итоге эти прения приходят к тому, что иудаизм, по Йехуде, выигрывает не внешней силой (скорее униженность его - знак избрания), не древностью и даже не сродством с иными монотеистическими религиями, а в первую очередь своей мистической традицией, непосредственно связанной с Синайским откровением. Знание, унаследованное от Адама, утверждает он, подкрепляется Божественным Логосом (амр Иллахи) ${ }^{12}$ и существует только у потомков Сима. Достоверная откровенная традиция

\footnotetext{
${ }_{11}$ Как выяснилось несколько позже на конференции, не только европейских.

${ }^{12}$ В оригинале «Кузари» написана по-арабски и лишь затем переведена на иврит. Об укорененности Йехуды в арабской (исламской) культуре, по замечанию докладчика, говорит уже то, что понятия кошерного и трефного у него без всяких оговорок обозначены как «халляль» и «харам».
}

и есть суть иудаизма, превышающая возможности и способности дискурсивного разума ${ }^{13}$. Отсюда исходит критика Аристотеля (который «слишком напряг разум, потому что не имел знания, основанного на достоверной Традиции»), арабских перипатетиков школы «фальсафа» (Йехуда многое берет у них, но лишь для обоснования идеи безусловного примата Откровенного знания), а также караимов, в противовес которым Йехуда отстаивает представление о Торе (в том числе раввинской Устной Торе) как о комплексе веры, знания и завета, а не просто о внешнем Законе.

От средневековой Испании конференция перенеслась на Дальний Восток, удержав свою основную проблему: «Вера и знание в японской мысли XIII в.» стали темой доклада Н. Н. Трубниковой. Этот век - эпоха первого сёгуната, или эпоха Камакура $^{14}$, - был промежутком между двумя большими смутами (наполненный смутами малыми). Для истории японской мысли, религии и культуры он был переломным. Буддизм в это время японизировался, появлялись новые его формы (дзен, амидаизм, учение Нитирэна), и в то же время он оказывал влияние на традиционный синтоизм, где впервые помимо обрядов появилось и учение.

Представление о том, как в XIII в. трактовалась проблема веры, дают притчи из различных сборников, например, из «Собрания песка и камней» (1280-е гг.). У человека пропал конь. Он обратился за советом к монаху. Тот велел ему пойти нарвать глицинии. Человек пошел за глицинией и встретил своего коня. Обнаженно-пародийно та же тема несколько позднее дана в «Записках от скуки» Ёсиды Кэнко (1330-е гг.): две редьки, которые человеку было зачем-то предписано потреблять ежедневно, в критический момент превратились в двух воинов, которые защитили его от грабителей. Это значит, что вера понимается как доверие, причем важен не предмет, а самый факт веры. Именно двусторонняя вера-доверие (син) - основа отношений человека и Будды.

Буддийская вера для японца XIII в. - не дар свыше: она полностью зависит от человеческой воли. Нигде вопрос не ставится так, что кто-то хочет верить, но не может: в каждом живом существе есть элемент природы, связанной с природой Будды, и достаточно желания, чтобы его пробудить. Однако опыт познания небесполезен для пробуждения веры. Полезно знать, что природа, совпадающая с природой Будды, существует: ведь если так, то всякому (даже и не Будде) есть смысл работать над освобождением других.

\footnotetext{
${ }^{13}$ Нетрудно увидеть здесь сходство с современными эзотерическими учениями; не менее важно, очевидно, было бы выявить и различия.

${ }_{14}$ Точные границы периода несколько шире: 1185-1333 гг.
} 


\section{Философия культуры}

Различались знание условное (обыденное или дискурсивное) и безусловное, освобождающее (мистическое, полученное в медитации). Если так, то неизвестно, есть ли истинное знание в книгах достаточно ли чтения книг, чтобы его получить. Скорее ответ должен быть отрицательным.

В XIII в. и монахи, и миряне переживали время «конца Закона». В эпоху мирового кризиса Закон уже может стать не посредником, а средостением между человеком и истинным Знанием. Встает вопрос, как разрушить это средостение. Многие (в первую очередь Нитирэн) полагали, что истинное знание можно обрести, только отвергнув ложное вместе с его носителями. Распространено было и обратное мнение: Истину можно найти всюду, любыми путями - например, бессмысленным чтением священных текстов. Элементарные житейские заботы, даже заботы о самом себе тоже включают в себя отблески Будды. В холод нельзя не закутываться, в жару нельзя не обмахиваться - следовательно, всякий сам себе Будда ${ }^{15}$. Вообще всякий о ком-нибудь да заботится, и нет разницы - заботиться о ближнем или жертвовать в храм. Но так как делать приходится что-то одно, встает вопрос о выборе веры: верить в Лотосовую сутру, в самого себя как Будду или в иное что.

Все это стало мощным интеллектуальным стимулом для теоретического самособирания синтоизма. В нем не идет речь об индивидуальной вере: боги существуют, веришь ты в них или нет, поэтому важно их почитать. Но через соотнесение с буддизмом приходят к мысли: отвергающий истинное Знание тем самым отвергает и почитание богов. В «Собрании песка и камней» богиня не может помочь вдруг обратившемуся к ней человеку, потому что он в нее не верит, а она, между тем, на самом деле - воплощение боддхисатвы.

Оборотной стороной серьезности веры было толерантное отношение к шутке и юмору. Рассказывали, будто кощунник и злодей, который передразнивал монаха, твердившего мантры, к собственному изумлению спасся уже за то, что произносил эти мантры, хотя и в шутку.

В прениях по этому докладу Б. Е. Рашковский обратил внимание, что проблематика выбора веры оказывается универсальной культурной константой, хотя в разных религиозно-цивилизационных условиях она проигрывается по-разному ${ }^{16}$.

\footnotetext{
15 Здесь кажется вполне уместным вспомнить слова апостола Павла: «... никто никогда не имел ненависти к своей плоти, но питает и греет ее, как и Господь Церковь, потому что мы члены тела Его, от плоти Его и от костей Его» (Еф. 5: 29-30).

${ }^{16}$ Представляется, что само изложение Н. Н. Трубниковой указывает на достаточно важные отличия японских текстов на эту тему от европейских. Во-первых, там не идет речь о прениях, потому что в большинстве буддийских
}

Доклад Т. Г. Скороходовой «Коллизия веры и знания как источник самопознания и праксиса (из истории “Бенгальского Ренессанса”)», как кажется, прямее всего соотносился с объявленной темой конференции, поскольку в нем было показано, как из конкретного, весьма своеобразного, религиозного опыта родилась цельная система философских и социальных взглядов.

Речь шла о мировоззрении лидеров общества «Брахмо Самадж»: его основателя Раммохана Рая, Дебендранатха Тагора и др. Акцент этого мировоззрения приходился на личностный - этический и мистический - аспект религии. Деятели «Бенгальского Ренессанса» стремились открыть специфический опыт индуизма для себя, для других и для всего мира в противостоянии традиционному индуистскому исповеданию, сторонники которого осуждали их за примат личного опыта над исполнением обрядов и соблюдением предписаний ${ }^{17}$.

Основой мировоззрения брахмоистов стала интуиция свободы - и внутренней, и религиозной, и социальной, но она сама по своей природе прежде всего религиозная. «У личности есть надежда, освободившись от ограничений религии ${ }^{18}$, обратиться к единому Духу», - говорил Раммохан Рай. У истоков этого освобождения стоит идея взаимопознания индуизма, ислама и христианства - трех религий, встретившихся на территории Бенгалии (самой передовой части Индийского субконтинента в XIX в.).

Все брахмоисты происходили из семей вишнуитов, многие, включая самого Раммохана Рая, из высокопоставленных брахманов. В их детском воспитании преобладала традиционная вера, но традиционное образование, направленное на интеграцию в общину, сочеталось с его другими формами. Всем им волей-неволей приходилось учить английский. Раммохан Рай получил первоначальное мусульманское образование и лишь затем его отправили учиться в Бенарес, чтобы увести от соблазнов иноверия - но это, в конечном счете, не удалось. Внутри Раммохана и его последователей произошло то, что Г. С. Померанц называет «монотеистической революцией», вследствие чего они выступали как реформаторы индуизма.

Измонотеизма-проблемымыслящей верыкак необходимой предпосылки человеческого служения Богу и людям - вытекает и прогрессизм участников «Брахмо Самадж». Свободу они понимали

учений пути спасения равночестны. Во-вторых и именно поэтому, выбор конкретного предмета веры в японской культуре сугубо вторичен по сравнению с выбором между верой и индифферентностью.

${ }_{17}$ Та же коллизия применительно к современности стала главным предметом рассмотрения в докладе И. Г. Яковенко. ${ }^{18}$ Т. е. традиционной религии. 
Культура и искусство 2(14) • 2013

и как единство с Богом, и как свободу для творчества («поиск внутренней церкви»). Насущной задачей для них было обогащение своей традиции в диалоге религий («не отвести зло, но сохранить добро»).

Еще одной религиозной интуицией брахмоистов было монотеистическое переживание Бога как творца реального, а не иллюзорного, как в индийских религиях, мира, как небесного Отца (чего также не было в индуизме). Отсюда вытекал нравственный императив любви, а из него - требование постоянного совершенствования сущего, особенно социального ${ }^{19}$. Это требование осознавалось как несовместимое с идолопоклонством.

Задача религии для деятелей Бенгальского Ренессанса - не соблюдение нормы, а совершенствование человека («любить Бога осмысленно из любви к истине»). Это сделало возможным совершить интеллектуально-нравственный прорыв для традиционного общества: установить осмысленное отношение «я - ты». Установленная в религиозном опыте связь Бога и мира стала основанием логической цепочки: социальное зло ведет к нравственной деградации, а она, в свою очередь, и к упадку самой религии. Отсюда борьба младобенгальцев за права женщин и другие социальные преобразования - требования, которые в конце концов стали основой программы Индийского национального конгресса.

С докладом на тему «Полидискурсность религиозной философии Соловьева» вновь выступил Е. Б. Рашковский. Докладчик предупредил, что разговор его будет выстроен несколько схематично, но для вхождения в проблему схематизм иной раз может оказаться небесполезен.

Полидискурсность - бросающаяся в глаза особенность Соловьева. Современники и исследователи видели в нем множество «личин»: философ, богослов, поэт, публицист, правозащитник, эколог, мистик, социальный утопист и пр. Но все это - один и тот же Соловьев. Можно убедиться, что на всем протяжении жизни, во всех родах деятельности он оставался всегда при одном и том же внутреннем задании, суть которого - собирание в каждую эпоху, в каждом регионе, в каждой конфессии распадающегося мира. И прежде всего собирание мира происходит в сознании, особенно в 1890-е гг., когда полидискурсность стала для него осознанным действием.

В творчестве Соловьева отчетливо выделяются три 10-летних периода.

1870-е г. для него - время мечты о «монодискурсе». В сфере интеллектуальной это универсаль-

\footnotetext{
${ }^{19}$ Из большого числа возможных аналогий в христианском мире прежде всего вспоминаются идеи В. Соловьева преимущественно (но не только) среднего периода.
}

ный синтез философии, науки, религии («цельное знание»). Проекциями идеи цельного знания на общее видение мироустройства становятся «свободная теософия», правовое государство, чистое искусство.

В 1880-е гг. эти мечты слились у Соловьева в мечту о «свободной теократии», «слишком либеральную для клерикалов и слишком клерикальную для либералов» ${ }^{20},-$ о гармонизации отношений между государственностью («царство»), религиозными институциями («священство») и свободной религиозной и общественной мыслью («пророчество»). С этим связаны такие особенности соловьевской мысли этих лет, как филокатолицизм с последующим расширением до экуменизма.

В последнее десятилетие жизни в Соловьеве растет разочарование в прежней рецептуре коллективного спасения мысли и мира. Поэтическим выражением настроений этого периода Е. Б. Рашковский считает стихотворение «Если желанья бегут словно тени...» (1893). Происходит переакцентировка всего учения: мой, твой, ваш собственный труд, собственное подвижничество - эти идеи выходят на первый план сверхзадачи собирания мира перед Богом и в Боге ${ }^{21}$. Поэтому массированные труды уже физически угасающего Соловьева идут, можно сказать, по всем направлениям. Их разнонаправленность и, следовательно, полидискурсность ясно видны из перечней задуманных и осуществляемых работ в письмах Н. А. Макшеевой (1897) и в редакцию «Нового времени» (уже почти предсмертное - 23 февраля 1899 г.). К ним надо еще добавить поэтическое творчество, требующее особого накала, особой отдачи.

Мысль Соловьева строится вокруг великой категориальной триады, образующей как бы стержень европейской философской традиции: Истина, Добро, Красота. Для Соловьева важно, что в нашем наличном мире они дискретны и неразменны, в Боге они конвергируют, но субъектный опыт веры есть основа их соотнесения во внутреннем мире человека и в человеческом общении. Субъективный опыт веры дает их соотнесение. Вера требуется не только в трансцендентные предметы, но и, скажем, в существование своего собеседника, без чего не может быть и веры в трансцендентное.

Разобщенность Истины, Добра и Красоты дает их противоположности. Ложь - это несоотнесенная самоправота абстрактного теоретического принципа («отвлеченного начала»). Зло - несоот-

${ }^{20}$ См. письмо В. С. Соловьева канонику Франё Рачкому от 9/21 декабря 1889 г. (Соловъев В. С. Собр. соч. Письма и приложения. Bruxelles: Жизнь с Богом, 1970. С. 179 первой паг.). ${ }^{21}$ Само собой разумеется, что речь может идти только о переакцентировке, да и то лишь в том смысле, что личный подвиг теперь ценится независимо от осуществимости идеала «всецелой общечеловеческой организации». 


\section{Философия культуры}

несенная самоправота морализма (народничество, толстовство, национализм как морализм для коллектива «своих»). Безобразие - несоотнесенная правота эстетизма (отсюда, в частности, неприятие нарождающегося декадентства). Характерно, что в 1890 г. был опубликован «Портрет Дориана Грея» О. Уайльда, дающий художественную картину такой разобщенности ${ }^{22}$.

Замысел Соловьева последних лет - «оправдание» всех верховных начал жизни. «Оправдание Истины» было предпринято в переиздании «Критики отвлеченных начал», во множестве статей по гносеологии и истории философии. «Оправданием Добра» стали одноименная книга и, не в меньшей степени, статья «Смысл любви». «Оправдание Красоты» рассеяно по многочисленным статьям о поэзии вообще, о Пушкине, Лермонтове, Тютчеве и т. д. Перед нами один и тот же Соловьев в несхожих, но взаимообогащающих дискурсах: метафизическом, этическом, эстетическом - и плюс еще в публицистическом, богословском, поэтическом. Собирание и облагорожение мира предпринимается не только в творческом субъекте, но и в его коммуникативном опыте - отсюда многообразие жанров, в которых трудится Соловьев: газета, лекция, научный журнал, энциклопедия.

Незадолго до смерти, к юбилею поэта, Соловьев написал статью «Значение поэзии в стихотворениях Пушкина» (1899), где, в частности, показал ступенчатую композицию стихотворения «Памятник», построфное восхождение: личность - поэзия - Родина - нравственные ценности - божественный суверенитет над творчеством. Этот разбор «Памятника» вместе с тем и акт самопознания великого философа, а для нас - документ, обосновывающий именно полидискурсность его творчества ${ }^{23}$.

\footnotetext{
22 У самого Соловьева она дана в «Краткой повести об Антихристе» (1900).

${ }^{23}$ В развитие темы доклада хотелось бы отметить еще два обстоятельства. Во-первых (и в связи с темой конференции) это определяющая роль личного, весьма своеобразного духовного опыта для всех поворотов жизни и мысли Соловьева. Во-вторых, особенно в последние годы жизни, поражает свобода его отношения к самым сложным мыслям, которая позволяла ему, например, так формулировать один из основополагающих тезисов гносеологии: «На вопрос, .. кому принадлежат данные психические факты, составляющие исходную точку философского рассуждения, можно и должно отвечать: неизвестно; может быть, никому; может быть, любой индивидуальности эмпирической: Ивану Ивановичу или Петру Петровичу, парижской модистке, принимающей себя за парижского архиепископа, или архиепископу, принимающему себя за модистку; может быть, наконец, тому общему трансцендентальному субъекту, который по причинам, совершенно неизвестным a prioiri, впал в иллюзию сознания...» (Соловъев В. С. Первое начало теоретической философии // Сочинения: В 2 т. М.: Мысль, 1988. Т. 1. С. 794). Нечто подобное можно, пожалуй, изредка встретить у Канта и Гегеля, но уж конечно не у Гуссерля, не у Хайдеггера и, между прочим, не у Бахтина - обличителя агеластов.
}

Второй день конференции открыл доклад А. Л. Рычкова «Николай Зёрнов и гнозисные искания русских символистов». Деятельность Н. М. Зёрнова и как богослова, и как собирателя книг знаменовалась встречей с православным опытом. Ссылаясь на В. Н. Лосского, докладчик подчеркнул, что слово «гнозис» в православии обозначает не только «лжеименное знание», но и то, что Исаак Сирин называет чувством вечной жизни - созерцание полноты божественной жизни ${ }^{24}$.

В зёрновской библиотеке находится немало книг, относящихся к истории гнозиса: «Сердце в христианской и индийской мистике» Б. П. Вышеславцева, «Старчик Григорий Сковорода» гр. П. А. Бобринского и др. Софийная тема представлена трудами А. Н. Шмидт, о. С. Н. Булгакова, о. П. А. Флоренского. Ряд работ ретроспективно рассматривает проблематику гнозиса в новиковском кружке, у Вл. Соловьева ${ }^{25}$.

В работах самого Зёрнова символизм рассматривается как отражение софийных исканий русского гнозиса. Русский «софийный гнозис» ставил особенно сильный акцент на человеческой стороне богочеловеческой коммуникации (Е. Б. Рашковский интерпретировал Софию в «софиологии» как присутствие в мире коммуникативного измерения) $)^{26}$. Символисты были особенно восприимчивы к нисхождению Софии в мир. Вяч. Иванов в нисхождении (кеносисе) Бога видел «красоту христианства», а красота для него знаменует вечное обручение Неба с Душою Мира.

Соловьев и за ним символисты восприняли мысль Валентина о создании мира из смеха и слез Софии Ахамот. У Соловьева в «Посвящении к неизданной комедии» (1880): «Из смеха звонкого и из глухих рыданий // Созвучие вселенной создано». Андрей Белый ту же тему (вхождение Софии Ахамот в Плерому) видел у А. Блока.

Символисты видели в поэзии особый род мистического опыта - «умное делание», теургическую задачу. Та же мысль встречается у Блока и Вяч. Иванова («уединившегося с Богом поэта... тайное умное делание»). Эти искания были несовместимы с тогдашним, по выражению Н.А. Бердяева, «церковным позитивизмом».

Гнозисные искания символистов предопределяли и их эсхатологию. Мережковский в грядущем «царстве Антихриста» видел последнюю страницу

\footnotetext{
${ }^{24}$ Ср. также: Лосский В. Н. Очерк мистического богословия Восточной Церкви. М., 1991. С. 163 и след. Здесь учение о «гносисе» как об «опытном восприятии нетварного света» на основании опыта святых отцов четко отграничивается от всего, с чем его можно спутать.

${ }^{25}$ См.: Библиотека Николая Михайловича Зернова: Каталог. М.: Центр книги, 2008.

${ }^{26}$ См.: Рашковский Е. Б. Осознанная свобода: Материалы к истории мысли и культуры XVIII - XX столетий. М.: Новый хронограф, 2005. C. 114-136.
} 
Культура и искусство 2(14) • 2013

истории, открывающую альтернативу: открытие Духа - или провал. Вслед за александрийскими «гностиками» 27 они ставили акцент на кризисности истории и культуры.

По ходу доклада оставалось не вполне понятным значение, в котором употребляется слово «гнозис». Отвечая на соответствующий вопрос Т. Г. Скороходовой, А. Л. Рычков определил его как «откровенное знание, несущее сотериологический смысл». Скороходова в ответ заметила, что для такой темы это слишком общее определение, покрывающее самые несходные явления...

Как параллельные были поставлены в программу доклады И. Г. Яковенко «Credo и cogito: Россия перед двойным вызовом» и А. А. Игнатьева «Credo и cogito: постмодерн перед двойным вызовом». В действительности они оказались различными, почти противоположными по подходу, но вместе дали стереоскопичную картину процессов, происходящих сейчас в русской и мировой культуре.

И. Г. Яковенко прежде всего оговорился, что его интересуют массовидные и статистически значимые процессы в обществе. Сейчас в России регулярно наблюдаются такие случаи, как убийство матери сыном при попытке изгнания беса или сына матерью по требованию гуру в ожидании конца света. Все это - проявления веры особого рода, полностью несовместимой с мыслью.

Зрелая, личностно окрашенная вера требует отрефлектированной жизни человеческого духа. Традиционалистская вера, напротив, - нерефлектирующая, ее содержание безличностно, абсолютно, императивно. Во всем новом душа традиционалиста узнает некоторые базовые структуры. Сакральная истина удостоверяется сакральными инстанциями («наша власть», «наша Церковь»). Наперекор тенденциям современности восстанавливается сословный характер общества.

В современном российском обществе личностная гносеология вступает в конфликт с «гносеологией» традиционалистской. Восстановление традиционалистской конфигурации сознания в секулярной стране приводит к появлению такого культурного персонажа, как православный активист с бейсбольной битой. Но в секулярную эпоху неизбежна и реакция на это - мощный антиклерикальный взрыв ${ }^{28}$. Рационализм всегда коррелирует с культурной зрелостью, в российской же

\footnotetext{
${ }_{27}$ Докладчик протестовал против употребления терминов «гностик», «гностицизм» в привычном, но, по его словам, отвергнутом современной наукой смысле. Мы позволили себе употребить это слово как отсылку к более или менее знакомому читателю явлению.

${ }_{28}^{8}$ Причем, заметим, секулярное сознание иронически проявляет себя как традиционное, «узнавая» в новом знакомые мифологемы («поп-черносотенец», «казак - гонитель свободы» и т. п.).
}

культуре рациональное начало подавлено, так и не встроилось в ее глубину. В современной ситуации это означает тенденцию провала страны в архаику.

Для традиционного мышления не императивны законы мысли и природы, но при этом традиционалистский канон тоже уже разрушен. В результате происходит накат оккультизма: примитивные мифы в винегрете с поверхностными обрывками науки. Для этого эклектического сознания исчезает поле свободы: человек тотально объектен, все, что происходит, - результат чьего-то заговора, но при этом все можно получить магией.

Все это - оборотная сторона крушения советского проекта, который, при всей его неразумности и аморальности, имел в себе и просвещенческий момент ${ }^{29}$. Однако докладчик закончил осторожным оптимизмом: носители традиционалистской чертовщины, по его мнению, - «Русь уходящая», а в молодом поколении он наблюдает гораздо большую предрасположенность к разумной вере. Долговременной перспективы нынешняя ситуация не имеет.

А. А. Игнатьев начал свое выступление с общетеоретических положений. Слова «credo» и «cogito»30 суть эмблемы двух альтернативных дискурсивных модальностей, «нераздельных и неслиянных» в реальности культуры: модальности мифа и модальности знания. Любое сообщение, если оно существенно, содержит в себе смыслы, но это смыслы разного рода. Знание выражает смыслы логически верифицируемые и совместимые с наличной реальностью ${ }^{31}$. Миф же всегда (даже в рационально-научных сферах) сопутствует маргинальным ситуациям.

За эмблемами «cogito» и «credo» стоят также дискурсивные и институциональные реальности науки и религии, причем в их диалектической связи. История их взаимоотношений практически совпадает с историей европейской мысли и может быть выбрана как возможный способ ее описания: циклическое чередование доминирования знания или веры.

${ }^{29}$ Встает, однако, вопрос, почему именно этот момент оказался самым нестойким из всего проекта (в то время как весь замысел «перестройки» был основан на ожидании обратного), а на поверхность вышли сильно трансформированные мифологемы того же порядка, как те, которые наблюдал в советской действительности А. Ф. Лосев (См.: Лосев А. Ф. Диалектика мифа // Лосев А. Ф. Миф, число, сущность. М.: Мысль, 1994. С. 103).

зо Вероятно, под влиянием выступления А. А. Игнатьева именно эти слова преимущественно употреблялись в дальнейших дискуссиях на конференции.

${ }^{31}$ Это положение сомнительно с точки зрения нынешней («постнеклассической») науки, для которой научные постулаты принципиально невыводимы из самой науки, т. е. должны приниматься «на веру». Однако с учетом такой reservatio mentalis оно, видимо, может работать для тех целей, которые ставил себе докладчик. 


\section{Философия культуры}

Европейская мысль как отличное от мифологии явление начинается с сократовского испытания предметов общераспространенной веры - деконструкции бытового мифа. Вслед за ним Платон вводит разграничение мнение («докса») и знания («эпистеме»). При этом класс, обладающий знанием («интеллигенция» в самом широком смысле слова), отделяется от тех, кто его не получил («простонародья»). Но поскольку знание и миф нераздельны, на деле интеллигенция от плебса и прежде, и теперь отличается только набором мифологем ${ }^{32}$.

В эпоху христианства особым статусом наделяется мнение (церковное), в которое постепенно кооптируется знание (у схоластов, а затем ренессансных мыслителей) В начале эпохи модерна знание вновь деконструирует господствующий миф и строит систему, основанную на науке, но миф берет реванш в области утопии. ${ }^{33}$ В советском обществе миф как таковой был объявлен несоответствующим идеалам общества. ${ }^{34}$

Нынешняя эпоха - вновь эпоха инверсии (имеет серьезный смысл вспомнить бердяевскую мысль о «новом средневековье»). Наблюдается, в первую очередь, кризис проектного сознания, характерного для нового времени. Крах больших проектов, обернувшихся тоталитаризмом, привел к примату всякого частного мнения. Важная предпосылка такой инверсии - разрастание медиа-сообществ с их культом плюрализма (и при этом беззаветной ненависти к религии и Церкви именно в среде журналистов). ${ }^{35}$ Вообще всякий кризис - время преимущественно мифа, а не знания.

В отличие от предыдущего докладчика, никакого осторожного оптимизма в оценке перспектив А.А. Игнатьев не испытывает. Вероятно, кризис разрешится либо возвращением в архаику, либо переходом к клерикализму как антидоту против нее, но и во втором случае также придется пожертвовать наукой и техникой. Сохранение же их в таком мифологизированном пейзаже - вопрос выживания нации, так как мифологизированное общество плохо воюет и плохо стреляет.

\footnotetext{
32 «Тем, что верит в другие глупости», как буквально выразился докладчик. Похоже, этот эпатирующий тезис может по-новому повернуть всю проблематику веры и знания в культуре.

${ }^{33}$ И поэзии, что можно было заключить из последовавшего обмена мнениями по этому вопросу.

34 Хотя вершиной всякой научности признавался миф о «светлом будущем», он же «научный коммунизм».

35 Последнее легко объяснимо именно тем, что примат мнения Церкви, конечно, несовместим с приматом любого (мнимо самостоятельного) мнения, на котором держится вся журналистика, включая самую субъективно добросовестную. С другой стороны, примат личного мнения вызревал уже и в недрах самого модерна и был отмечен X. Ортегой-и-Гассетом как одна из черт «восстания масс»«право быть неправым».
}

Последним событием конференции стала презентация только что вышедшей в свет книги T.Г Скороходовой «Младобенгальцы». ${ }^{36}$ Анализ самой книги - многоаспектного исторического и проблемного исследования бенгальской мысли первой половины XIX в. - не может быть предметом этого обзора. Мы лишь изложим основные положения, которые автор произнесла, представляя свою работу, - фактически, это был еще один доклад.

История младобенгальцев (поэта и просветителя Генри Дерозио, его учеников и последователей) представляется модельной ситуацией интеллектуальных аспектов внезапных модернизаций. В их деятельности и в их конфликте с окружающим обществом исследовательница видит не конфликт религии и атеизма (младобенгальцы не были атеистами, некоторые из них перешли в христианство), а конфликт персонализма с традиционной религией (в данном случае индуизмом). Переворачивая известное выражение Г. Гессе, деятели бенгальского Возрождения совершали интеллектуальное «паломничество в страну Запада». Биография самого Дерозио позволяет раскрыть предпосылки конфликта персонализма с традиционализмом. ${ }^{37}$

В заключение выступления была поставлена важная проблема: для анализа любой цивилизации необходимо выяснить, как в ней обстоит дело с отношением credo и cogito. Иначе она формулируется как проблема религиозно-цивилизационных фундаментов.

Заслуживают упоминания некоторые из мыслей, прозвучавших во время общего обсуждения. Т.Г. Скороходова так обозначила проблематику конференции: «credo» и «cogito» как универсальная проблема, но в разных цивилизационно-культурных преломлениях. Оно обратила на связь между двумя днями конференции. Первый был посвящен преимущественно востоковедной тематике, второй - проблемам современности. Выясняется, что восточные смыслы обращают к современным, в том числе к вектору свободы в любом пространстве. А.А. Игнатьев высказал мнение, что тему «credo» и «cogito» особенно интересно изучать не на чистых, а на периферийных, маргинальных культурах и субкультурах. При этом диалектика «credo» и «cogito» оказывается как бы сердцевиной проблематики модернизации. Е.Б. Рашковский, возвращаясь к докла-

\footnotetext{
${ }^{36}$ Скороходова Т. Г. Младобенгальцы: очерки социальной мысли Бенгальского Возрождения (Первый период, 18151857). СПб.: Петербургское востоковедение, 2012.

37 Непосредственно описанию столкновения Дерозио с ортодоксальными индуистами, поддержанными частью колониальной администрации, посвящены с. 63 и след. книги.
} 


\section{Культура и искусство 2(14) • 2013}

ду Т.Г. Скороходовой, сделанному в первый день, выделил в нем проблему соотношения этики и мистики. Этическое у деятелей Бенгальского Возрождения мистично, мистическое - в глубине его - этично. Ни мистическая реальность, ни потребность не только возлюбить, но и понять ближнего не даны нам как прямые данные нашего сознания. Но мистическое чувство развивает нашу нравственную рефлексию, тогда как постижение другого человека усугубляет нашу интуицию таинственного Бога и Бытия. ${ }^{38}$

Затем он подвел общие итоги конференции. В ней выделяется четыре главных тематических горизонта: библейский, востоковедный; российский; мировой. Но независимо от обращения к той или иной конкретной культуры в докладах выявлялась не «неслиянность и нераздельность», а дополнительность опыта веры и опыта познания - credo и cogito. Эту дополнительность можно уподобить гейзенберговской или «инь-ян», но притом она весьма драматична. Соблазн устранить один из членов пары ведет к мыслительному уродству: вера без cogito есть слепота, cogito без веры - coлипсизм и сумасшедший дом. В любом случае финалом будет террористическая диктатура, то есть политическая ипостась все того же сумасшедшего дома. В целом отношения веры и знания раскрываются, как одна из важнейших драматических, но вместе с тем и творческих коллизий в истории мировой и, в частности, отечественной культуры.

\section{Список литературы:}

1. Библиотека Николая Михайловича Зернова: Каталог. М.: Центр книги, 2008.

$2 . \quad$ Библия. Книги Священного писания Ветхого и Нового Завета канонические. М.: РБО, 2011.

3. Скороходова Т. Г. Младобенгальцы: очерки социальной мысли Бенгальского Возрождения (Первый период, 1815-1857). СПб.: Петербургское востоковедение, 2012.

4. Соловьев B. С. Собрание сочинений. Письма и приложения. Bruxelles: Жизнь с Богом, 1970.

\section{References (transliteration):}

1. Biblioteka Nikolaya Mikhaylovicha Zernova: Katalog. M.: Tsentr knigi, 2008.

2. Bibliya. Knigi Svyashchennogo pisaniya Vetkhogo i Novogo Zaveta kanonicheskie. M.: RBO, 2011.

3. Skorokhodova T.G. Mladobengal'tsy: ocherki sotsial'noy mysli Bengal'skogo Vozrozhdeniya (Pervyy period, 18151857). SPb.: Peterburgskoe vostokovedenie, 2012.

4. Solov'ev V. S. Sobranie sochineniy. Pis'ma i prilozheniya. - Bruxelles: Zhizn’ s Bogom, 1970

\footnotetext{
${ }^{38}$ Все это самым явным образом перекликается с основными интенциями творчества Владимира Соловьева.
} 